\section{A case for instant peer review?}

SIR - I should like to comment on your News story ${ }^{1}$ arising from a recent meeting at the Royal Society and on an earlier leading article about peer review ${ }^{2}$.

My colleagues and I have repeatedly praised McKay et al. ${ }^{3}$ for their courage in reporting the possibility of fossil life in a martian meteorite. My group's scientific record is documented by Nature ${ }^{4-6}$, so there was never any necessity to use the meeting "Searching for Life in the Solar System and Beyond" (SLSSB) as a forum to make any personal statement claiming precedence; in fact the meeting was the brainchild of Dr Alan Penny of the Central Laboratory for the Research Councils and was $40 \%$ devoted to searching for life around stars other than the Sun, in addition to discussing issues concerning Mars.

Further, I would like to correct a number of errors in the News story: (1) no press release containing data from anyone attending SLSSB was issued before 1250 hours on 31 October; (2) Ian Wright's very responsible comments to the press concerning Wright et al. ${ }^{4}$ were that "our data do not show one way or the other" rather different from discounting explicitly the possibility of life on Mars; and (3) no journalist was given an exclusive interview by anyone; indeed, Nature was offered the same opportunity as a number of other journalists - a personal invitation to attend the scientific sessions of SLSSB.

Nature is entitled to adopt any policy it wants on scientists talking to the press ${ }^{2}$. As Gresham Professor of Astronomy, I want to encourage scientific understanding of "new learning" as Sir Thomas Gresham would have wished 400 years ago when he gave money for public awareness activities. How can scientists expect the public to become interested in our work if we continue to tell them the issues are too complex for them to understand?

Finally, I believe that I, my co-authors and everyone involved in SLSSB have behaved impeccably. The media blackout before Wright stood up before his peers was totally effective. We offered ourselves on 31 October, as Ian Taylor MP, Minister for Science and Technology, so nicely put it, "for instant peer review".

\section{T. Pillinger}

Planetary Sciences Research Institute, Open University,

Milton Keynes MK7 6AA, UK

e-mail: psri@open.ac.uk

SIR - A recent leading article ${ }^{2}$ criticizes the use of the popular media as outlets for scientific information and states categorically that publication in peer-reviewed journal is an essential prerequisite for public discussion.
Strict pre-publication peer-review procedures as applied by Nature and other scientific journals are a relatively new phenomenon in the history of science. Most of this history witnessed publication of major works (Copernicus, Darwin) without strong reliance on peer review, followed by public discussion in print by peers. In this way the entire process of the exchange of scientific arguments was transparent and allowed to bring science closer to the public.

Today, peer review suppresses debates in print, forces them to take place anonymously through editorial offices and produces publications containing compromise statements. It emasculates scientific debates and hinders publication of nonconsensus views.

Negative aspects of peer review have been well recognized. David Goodstein recently stated ${ }^{7}$ that the process of peer review encourages what he calls "scientific misconduct" as "referees are never called to account for what they write in their reviews". Because referees often have a conflict of interest with authors, it is naive to believe that in their anonymity they will remain meticulously impartial.

Even at the beginning of the century, it was editors of scientific journal who made decisions about publication of submitted manuscripts. As specialization increased, editors sought the advice of experts in rapidly narrowing fields but still made their own decisions. Finally it has been discovered that a major portion of editorial decision can be de facto made by referees.

With peer review stifling scientific communication, it is no wonder that scientists, being mostly creative people, are seeking alternative ways of making their findings and interpretations public. Scientific journals are, after all, a part of the 'media industry' selling information. So you are subject to the normal rules of a competitive market.

In the era of worldwide journalism and Internet communication, standard ways of disseminating scientific information are becoming too cumbersome, and no amount of pleading and threats to authors who talk to the media before subjecting themselves to a delaying quagmire of peer review will prevent the change.

Science thrives on unencumbered flow of information and exchange of arguments and will naturally use new opportunities in

\footnotetext{
1. Masood E. Nature 384, 3-4 (1996).

2. Nature 383, 745 (1996).

McKay D. S. et al. Science 273, 924-930 (1996)

4. Wright I. P., Grady, M. M. \& Pillinger C. T. Nature 372, 340 220-222 (1989).

5. Carr R. H. et al. Nature 314, 248-250 (1985).

6. Romanek C. S. et al. Nature 372, 655-657(1994)

7. Goodstein, D. Ann. N. Y. Acad. Sci. 775, 35-38 (1996).
}

this regard. I am sure that Nature will respond creatively to the challenges of the market and maintain its present role of a leading purveyor of scientific information. Maciej Henneberg Department of Anatomy, University of Adelaide, Adelaide 5005, Australia

\section{Cistron has guts}

SIR - I read with disappointment your leading article "Peer review and the courts" (Nature 384, 1; 1996). You denigrate Cistron Biotechnology for being a small company, and reveal your misunderstanding of the importance of IL-1 technology.

As you should be aware, IL-1 is the initiator of the human immune response. IL-1 has been a vital tool in the discovery and development of promising therapies such as IL-1 receptors and protease inhibitors and in apoptosis studies. The fact that Immunex Corporation tested the 'mature' fragment, a fragment that elicits a high level of biological activity, and found it to be toxic in clinical trials is not surprising. Other IL-1 fragments of mutants, as well as the precursor form of IL-1 itself, may well prove to be therapeutically useful.

Cistron may be a small company, but it is a publicly held company, and our shareholders would take a dim view of your suggestion that the proceeds of the litigation settlement be divided among our employees and that we take "early retirement".

I would expect better of Nature, especially since our lawsuit accused Immunex of stealing our IL-1 sequence from an unpublished manuscript submitted to your journal. At least Cistron had the guts to stand up for the peer-review system.

\section{Bruce C. Galton}

Cistron Biotechnology,

Box 2004,

10 Bloomfield Avenue,

Pine Brook, New Jersey 07058, USA

\section{Prior publication}

SIR - When you wrote about the report, in "50 years ago", on locating radiumlabelled click beetles (Agriotes sp.) with a Geiger-Müller counter (Nature 17 October 1996, ix), you might have mentioned a method described many years earlier by J. M. Barrie, whereby the sound of ticking served to localize a crocodile that had ingested an 8-day alarm clock.

\section{Ralph A. Lewin}

Scripps Institute of Oceanography, University of California, San Diego, La Jolla, California 92093-02302, USA 